\title{
Physicochemical and Microbiological Quality of Potable Water Supplied by DWASA in Dhaka City of Bangladesh
}

\author{
A. H. M. Shofiul Islam Molla Jamal*, Md. Aminul Ahsan, Shamim Ahmed, Shakila Akter, \\ Rokaia Sultana, Aynun Nahar, Md. Ripaj Uddin
}

Institute of National Analytical Research and Service (INARS), Bangladesh Council of Scientific and Industrial Research (BCSIR), Dhanmondi, Dhaka, Bangladesh

\author{
Email address: \\ shofiuljamal@yahoo.com (A. H. M. S. I. M. Jamal) \\ *Corresponding author
}

To cite this article:

A. H. M. Shofiul Islam Molla Jamal, Md. Aminul Ahsan, Shamim Ahmed, Shakila Akter, Rokaia Sultana, Aynun Nahar, Md. Ripaj Uddin. Physicochemical and Microbiological Quality of Potable Water Supplied by DWASA in Dhaka City of Bangladesh. American Journal of Biological and Environmental Statistics. Vol. 6, No. 1, 2020, pp. 1-6. doi: 10.11648/j.ajbes.20200601.11

Received: December 30, 2019; Accepted: January 10, 2020; Published: February 4, 2020

\begin{abstract}
Dhaka is the largest and fastest-growing urban city in Bangladesh with a population density of $44,500 / \mathrm{km}^{2}$. Dhaka Water Supply and Sewerage Authority (DWASA) is the sole legal entity to develop and maintain a water supply system for city people. 78\% DWASA water comes from underground-which leads to incremental depletion of groundwater. In this condition, reducing groundwater dependence and switching to surface water is the only way forward. Growing and increasingly wealthier population, climate change and the urbanization process deteriorate the Shitalakshya River which is the surface water source of DWASA. The purpose of this study was to investigate the DWASA supplied water quality around Dhaka city. Physicochemical and microbiological Parameters were analyzed by American Public Health Association (APHA) standard methods. The measured $\mathrm{pH}$ value (6.58-7.03) and Dissolved Oxygen (DO) value (6.10-7.50 $\mathrm{mg} / \mathrm{L}$ ) of samples indicate safe potable water. Calcium and Magnesium were found at a significant level. Both of these elements are essential for the human body. There were no heavy metals contamination in water supplied by DWASA. Total Coliforms and Fecal Coliforms of all samples showed less than $0.2 \mathrm{MPN} / \mathrm{mL}$ (most probable number $<0.2$ indicates absence of test organism in $1 \mathrm{~mL}$ ). Total Viable Count (TVC) of all samples were less than $100 \mathrm{cfu} / \mathrm{mL}$. The observed result was compared to acceptable limit of drinking water of Bangladesh Standards and Testing Institution (BSTI) and Environment Conservation Rules, 1997, Bangladesh guideline. This study demonstrated that in general the potable water quality status of Dhaka city ranged from excellent to good.
\end{abstract}

Keywords: Bangladesh, Potable Water, Physicochemical Properties, Heavy Metals, Microbiological Parameters

\section{Introduction}

Dhaka is the capital and largest city of Bangladesh. It is one of the largest and most densely populated cities in the world, with a population of 20.20 million people in the Greater Dhaka Area [1]. Dhaka Water Supply and Sewerage Authority (DWASA) is a service oriented autonomous commercial organization in the Public Sector, entrusted with the responsibility of providing water supply, sewerage disposal (wastewater), and storm water drainage service to the urban dwellers of Dhaka City [2]. DWASA covers more than 360 sq. $\mathrm{km}$ service area with more than 1.7 million people with a production capacity of 2500 million liters water per day (MLD). DWASA was established in the year 1963 as an independent organization and currently which is running under DWASA ACT 1996. Its vision is to be the best water utility in the public sector of Asia-Environment friendly, sustainable and pro people water management system [2].

DWASA is improving day by day and has become a role model in the public sector utility services among the SAARC Countries. By 2021 the ratio of surface and underground sources is targeted to 70: 30 , which is currently 22:78 ratios. Ground water is abstracted by using a total No. of 827 deep tube wells. Surface water is supplied by treating water of the Shitalakshya River through Water Treatment Plant (WTP). There are a lot of methods of surface water treatment for 
drinking and domestic purposes [3-6]. DWASA water treatment process includes: Water Intake, Aeration, Biological Pretreatment, Clarifier, Rapid Sand Filter, Chlorination, Storage, and Distribution Network [7-10].

A lot of studies were carried out of surface water in and around Dhaka city $[11,12]$. In some studies reported the pollution level of the Buriganga and the Shitalakshya River water with industrial effluent. [13, 14]. With the best of our knowledge no studies has been reported yet in assessment of physicochemical and microbiological parameters of potable water supplied by DWASA after treatment in WTP. In this study we try to find out the physicochemical and microbiological properties of potable water that come from treating the Shitalakshaya River water by Dhaka DWASA WTP.

\section{Materials and Method}

\subsection{Study Area}

The samples were collected from different areas of Dhaka city covering the whole Dhaka north and south municipal area. Samples were collected from eleven (11) points. The sampling points were located at Azimpur, Lalbag, Elephant Road, Gulistan, Sayedabad, Rampura, Uttara, Mirpur-1, Agargaon, Asadgate and Shewrapara.

\subsection{Sample Collection}

In this study, for the analysis of physicochemical and microbiological properties, samples were collected from sampling area's city dwellers houses. The samples were collected in clean bottle with labeling a unique identification no. (Table 1) for each sample, and stored at $4{ }^{\circ} \mathrm{C}$ prior to analysis. 1 liter plastic bottles were used for collecting samples for physicochemical analysis and 0.5 liter sterilized glass bottles were used for collecting samples for microbiological parameter analysis. Prior to collection, the plastic bottles were cleaned by detergent solution and then, it was treated with $5 \%$ nitric acid overnight. They were finally washed with deionized water and dried in the air. During sampling the sample bottles were tightly screwed. The $\mathrm{pH}$, electrical conductivity EC) and total dissolved solids (TDS) were measured at the site during sample collection. Then samples were kept in ice bag tied well. Then, it was carried to the laboratory and stored in the refrigerator. Collection and analysis of the samples were performed in May, 2019 by proper sampling procedure.

\subsection{Sample Analysis}

$\mathrm{pH}$, Temperature and Electrical Conductivity were measured at the sampling point and the other parameter TDS, DO, heavy metals, anions, E-Coli, Total Coliform, and Total Plate Count of the samples were analyzed at institute of national analytical research and service (INARS) of Bangladesh Council of Scientific and Industrial Research (BCSIR) by American Public Health Association (APHA) standard methods [15].

The temperature of water was recorded with the help of a thermometer calibrated from Cali-lab, India. pH, EC and DO were measured by portable multi parameter meter (SenionTM156, HACH, USA). TDS was determined gravimetrically by following standard methods mentioned in APHA (1998). A certain amount of samples were filtered by using Whatman 44 filter paper followed by drying at $180^{\circ} \mathrm{C}$ in a calibrated oven for measuring TDS.

Analysis of metals- Arsenic (As), Iron (Fe), Magnesium (Mg), Calcium (Ca), Lead (Pb), Mercury (Hg), Zinc ( $\mathrm{Zn})$ and Cadmium (Cd) were measured by atomic absorption spectrometry. $100 \mathrm{~mL}$ sample was digested in $5 \mathrm{~mL} \mathrm{HNO}_{3}$ on a hot plate in fume hood. The sample was gently boiled to the lowest possible volume until digestion completed as shown by a light color, clear solution. After complete digestion, cool sample was transferred to $100 \mathrm{~mL}$ volumetric flask and diluted up to the mark. The sample was then filtered. $\mathrm{Pb}, \mathrm{Cd}$, $\mathrm{Hg}$ and $\mathrm{Ni}$ were analyzed by Graphite Furnace Atomic Absorption Spectrometer (Model GTA 120, Varian, Australia). As was analyzed by hydride generation technique using Atomic Absorption Spectrometer (Model GTA 120, Varian, Australia). Fe, $\mathrm{Ca}, \mathrm{Mg}$ and $\mathrm{Zn}$ were analyzed by Flame Atomic Absorption Spectrometer (Model AA240FS, Varian, Australia). In case of high concentration, the sample was diluted by using de-ionized water [16-17].

Anions $\left(\mathrm{F}^{-}, \mathrm{Cl}^{-}, \mathrm{Br}^{-}, \mathrm{NO}_{2}{ }^{-}, \mathrm{NO}_{3}{ }^{-}, \mathrm{SO}_{4}{ }^{2-}\right)$ were measured using Ion Chromatograph (SIC10AVP, Shimadzu, Japan). Samples were filtered through 0.22 micron filter to avoid dust particles. $1.3 \mathrm{mM}$ Sodium carbonate $\left(\mathrm{Na}_{2} \mathrm{CO}_{3}\right)$ and 1.7 $\mathrm{mM}$ Sodium bi-carbonate $\left(\mathrm{NaHCO}_{3}\right)$ mixer was used as a mobile phase to separate ions in an ionic chromatographic column (HIC 10A super).

\subsection{Calibration Standards Used for Sample Analysis}

Zero solution ( $5 \% \mathrm{NaSO}_{2}$ solution), buffer solutions $(\mathrm{pH}=4.0, \mathrm{pH}=7.0), 1000 \mu \mathrm{S} / \mathrm{cm}$ of $\mathrm{NaCl}$ solution were used to calibrate portable multi parameter meter for determining DO, pH \& conductivity, respectively. $1000 \mathrm{mg} / \mathrm{L}$ stock metals and anions standard (Scharlau, Spain) solutions were used to prepare calibration standards. The stock standards were diluted to certain concentration of calibration standards required to measure different metals by AAS.

Table 1. Sample identification no.

\begin{tabular}{llll}
\hline Sampling area & Sample identification No. & Sampling area & Sample identification No. \\
\hline Azimpur & W-101 & Uttara & W-107 \\
Lalbag & W-102 & Mirpur-1 & W-108 \\
ElepHant Road & W-103 & Agargaon & W-109 \\
Gulistan & W-104 & Asadgate & W-110 \\
Sayedabad & W-105 & Shewrapara & W-111 \\
Rampura & W-106 & & \\
\hline
\end{tabular}


Table 2. Physicochemical parameters of drinking water.

\begin{tabular}{lllll}
\hline Sample ID & $\mathbf{p H}$ & $\mathbf{D O}(\mathbf{m g} / \mathbf{L})$ & $\mathbf{E C}(\boldsymbol{\mu} \mathbf{S} / \mathbf{c m})$ & TDS $(\mathbf{m g} / \mathbf{L})$ \\
\hline W-101 & 6.78 & 7.20 & 476 & 230 \\
W-102 & 6.62 & 7.49 & 418 & 202 \\
W-103 & 6.60 & 7.31 & 589 & 286 \\
W-104 & 6.62 & 7.50 & 709 & 345 \\
W-105 & 6.58 & 7.35 & 291 & 139 \\
W-106 & 7.35 & 247 & 118 \\
W-107 & 6.10 & 6.10 & 227 & 108 \\
W-108 & 6.72 & 7.35 & 286 & 136 \\
W-109 & 6.82 & 7.22 & 379 & 182 \\
W-110 & 7.06 & 7.35 & 247 & 118 \\
W-111 & 7.01 & & 362 & $500 \mathrm{mg} / \mathrm{L}$ \\
BSTI [9] & 6.85 & -- & $1000 \mathrm{mg} / \mathrm{L}$ \\
ECR-1997 [10] & $6.4-7.4 \mathrm{mg} / \mathrm{L}$ & 6.0 & -- & \\
\hline
\end{tabular}

\section{Results and Discussion}

$\mathrm{pH}$ of all collected samples was between 6.58 and 7.06. The acceptable limit of $\mathrm{pH}$ for drinking water according to BDS (Bangladesh Standards) 1240:2001 is 6.4-7.4. BDS is supplied by Bangladesh Standards and Testing Institution (BSTI). BSTI is a government agency under the Ministry of Industries of Bangladesh constituted for the purpose of controlling the standard of service and quality of the goods [18]. The temperature of all samples was between $24.7^{\circ} \mathrm{C}$ and $25.3^{\circ} \mathrm{C}$. The observed Dissolved Oxygen (DO) was between 6.10 and 7.50. According to Environment Conservation
Rules (ECR) 1997, Bangladesh DO value is 6.0 [19]. Actually raw water is drawn from the Sitalakhya River through an intake pumping station known as 'Sarulia pumping station'. It is then transmitted through a $40 \mathrm{~m}$ wide and $4.6 \mathrm{~km}$ long canal, known as the 'DND canal'. Aerator has been installed at a varied location in the DND canal to increase the oxygen level in the raw water.

The range of Total dissolved solids (TDS) was between $108-345 \mathrm{mg} / \mathrm{L}$. The value of TDS of W-101 and W-104 were $108 \mathrm{mg} / \mathrm{L}$ and $345 \mathrm{mg} / \mathrm{L}$ respectively. The acceptable limit of TDS according to BSTI and ECR-1997 is $500 \mathrm{mg} / \mathrm{L}$ and $1000 \mathrm{mg} / \mathrm{L}$ respectively.

Table 3. Heavy metal of drinking water.

\begin{tabular}{|c|c|c|c|c|c|c|c|c|c|}
\hline Serial no. & Sample No. & $\operatorname{AS}(\mathrm{mg} / \mathrm{L})$ & $\mathrm{Fe}(\mathrm{mg} / \mathrm{L})$ & $\operatorname{Mg}(\mathrm{mg} / \mathrm{L})$ & $\mathrm{Ca}(\mathrm{mg} / \mathrm{L})$ & $\mathrm{Pb}(\mathrm{mg} / \mathrm{L})$ & Hg (mg/L) & $\mathrm{Zn}(\mathrm{mg} / \mathrm{L})$ & $\mathrm{Cd}(\mathrm{mg} / \mathrm{L})$ \\
\hline 01 & W-101 & $<0.005$ & 0.451 & 15.0 & 41.4 & $<0.01$ & $<0.001$ & $<0.1$ & $<0.001$ \\
\hline 02 & W-102 & $<0.005$ & 0.471 & 15.4 & 38.3 & $<0.01$ & $<0.001$ & $<0.1$ & $<0.001$ \\
\hline 03 & W-103 & $<0.005$ & $<0.2$ & 15.4 & 46.5 & $<0.01$ & $<0.001$ & $<0.1$ & $<0.001$ \\
\hline 04 & W-104 & $<0.005$ & 0.27 & 16.2 & 70.7 & $<0.01$ & $<0.001$ & $<0.1$ & $<0.001$ \\
\hline 05 & W-105 & $<0.005$ & $<0.2$ & 9.35 & 22.1 & $<0.01$ & $<0.001$ & $<0.1$ & $<0.001$ \\
\hline 06 & W-106 & $<0.005$ & $<0.2$ & 7.86 & 15.2 & $<0.01$ & $<0.001$ & $<0.1$ & $<0.001$ \\
\hline 07 & W-107 & $<0.005$ & $<0.2$ & 12.5 & 16.0 & $<0.01$ & $<0.001$ & 0.57 & $<0.001$ \\
\hline 09 & W-109 & $<0.005$ & 0.786 & 16.1 & 24.8 & $<0.01$ & $<0.001$ & $<0.1$ & $<0.001$ \\
\hline 10 & W-110 & $<0.005$ & $<0.2$ & 6.64 & 14.8 & $<0.01$ & $<0.001$ & $<0.1$ & $<0.001$ \\
\hline 11 & W-111 & $<0.005$ & 0.741 & 12.2 & 25.9 & $<0.01$ & $<0.001$ & 0.56 & $<0.001$ \\
\hline \multicolumn{2}{|l|}{ BSTI [9] } & 0.01 & 0.3 & -- & 75 & 0.01 & 0.001 & 3.0 & 0.003 \\
\hline \multicolumn{2}{|c|}{ ECR-1997 [10] } & 0.05 & $0.3-1.0$ & $30-35$ & 75 & 0.05 & 0.001 & 5.0 & 0.005 \\
\hline
\end{tabular}

Arsenic value of all sampling areas was less than 0.005 $\mathrm{mg} / \mathrm{L}$. The acceptable limit of Arsenic according to BSTI and ECR-1997 is $0.01 \mathrm{mg} / \mathrm{L}$ and $0.05 \mathrm{mg} / \mathrm{L}$ respectively. Iron value of most of the sampling areas was less than $0.2 \mathrm{mg} / \mathrm{L}$. The Iron value of W-101 $(0.451 \mathrm{mg} / \mathrm{L}), \mathrm{W}-102(0.471 \mathrm{mg} / \mathrm{L})$, W-109 $(0.786 \mathrm{mg} / \mathrm{L})$ and $\mathrm{W}-111(0.741 \mathrm{mg} / \mathrm{L})$ were slightly higher than BSTI standard $(0.3 \mathrm{mg} / \mathrm{L})$ but within the limit of ECR-1997 (0.3-1.0 mg/L). Magnesium value of collected samples is less than acceptable limit $(30-35 \mathrm{mg} / \mathrm{L})$ according to ECR-1997. Magnesium value range was between 6.64 $\mathrm{mg} / \mathrm{L}$ and $16.2 \mathrm{mg} / \mathrm{L}$. Calcium value of collected samples was less than acceptable limit $(75 \mathrm{mg} / \mathrm{L})$ according to BSTI and ECR-1997. W-110 showed the lower value (Mg- 6.4 $\mathrm{mg} / \mathrm{L}, \mathrm{Ca}-14.8 \mathrm{mg} / \mathrm{L}$ ) and $\mathrm{W}-104$ showed the higher value (Mg- $16.2 \mathrm{mg} / \mathrm{L}, \mathrm{Ca}-70.7 \mathrm{mg} / \mathrm{L}$ ) of Magnesium and Calcium among all sampling areas. Calcium and Magnesium were found at a significant level in all samples. Ca \& $\mathrm{Mg}$ are essential for the human body. Calcium is part of bones and teeth. In addition, it plays a role in neuromuscular excitability (decreases it), good function of the conducting myocardial system, heart and muscle contractility, intracellular information transmission and blood coagulability. Osteoporosis and osteomalacia are the most common manifestations of calcium deficiency. The recommended $\mathrm{Ca}$ daily intake for adults ranges between 700 and $1000 \mathrm{mg}$. Magnesium plays an important role as a cofactor and activator of more than 300 enzymatic reactions including glycolysis, ATP metabolism, transport of elements such as $\mathrm{Na}, \mathrm{K}$ and $\mathrm{Ca}$ through membranes, synthesis of proteins and nucleic acids, neuromuscular excitability and muscle 
contraction etc. It acts as a natural antagonist of calcium. Magnesium deficiency increases risk to humans of developing various pathological conditions such as vasoconstrictions, hypertension, cardiac arrhythmia, atherosclerotic vascular disease, acute myocardial infarction, eclampsia in pregnant women, possibly diabetes mellitus of type II and osteoporosis. The recommended magnesium daily intake for an adult is about 300-400 mg [20]. All sampling areas showed the lead $(\mathrm{Pb})$ value less than $0.01 \mathrm{mg} / \mathrm{L}$. The acceptable limit of lead $(\mathrm{Pb})$ according to BSTI and ECR-
1997 is $0.01 \mathrm{mg} / \mathrm{L}$ and $0.05 \mathrm{mg} / \mathrm{L}$ respectively. The Mercury and Cadmium value of all samples were less than 0.001 $\mathrm{mg} / \mathrm{L}$. BSTI and ECR-1997 recommends the mercury value of drinking water is less than $0.001 \mathrm{mg} / \mathrm{L}$. The acceptable limit of Cadmium is $0.003 \mathrm{mg} / \mathrm{L}$ (BSTI) but $0.005 \mathrm{mg} / \mathrm{L}$ (ECR-1997). The observed Zinc value of nine sampling areas was less than $0.01 \mathrm{mg} / \mathrm{l}$. W-107 and $\mathrm{W}-111$ showed the Zinc value $0.57 \mathrm{mg} / \mathrm{L}$ and $0.56 \mathrm{mg} / \mathrm{L}$ respectively. The acceptable limit of Zinc is $3.0 \mathrm{mg} / \mathrm{L}$ (BSTI) but $5.0 \mathrm{mg} / \mathrm{L}$ (ECR-1997).

Table 4. Anions of drinking water.

\begin{tabular}{|c|c|c|c|c|c|c|c|}
\hline Serial no. & Sample No. & $\begin{array}{l}\text { Fluoride } \\
(\mathrm{mg} / \mathrm{L})\end{array}$ & $\begin{array}{l}\text { Chloride } \\
(\mathrm{mg} / \mathrm{L})\end{array}$ & Nitrite (mg/L) & $\begin{array}{l}\text { Bromide } \\
\text { (mg/L) }\end{array}$ & $\begin{array}{l}\text { Nitrate } \\
(\mathrm{mg} / \mathrm{L})\end{array}$ & Sulphate (mg/L) \\
\hline 01 & W-101 & $<0.5$ & 26.8 & $<1.0$ & $<1.0$ & $<3.0$ & 7.7 \\
\hline 02 & W-102 & $<0.5$ & 17.6 & $<1.0$ & $<1.0$ & $<3.0$ & 26.0 \\
\hline 03 & W-103 & $<0.5$ & 59.2 & $<1.0$ & $<1.0$ & 14.2 & 26.6 \\
\hline 04 & W-104 & $<0.5$ & 72.2 & $<1.0$ & $<1.0$ & 14.3 & 23.3 \\
\hline 05 & W-105 & $<0.5$ & 10.4 & $<1.0$ & $<1.0$ & $<3.0$ & 5.4 \\
\hline 06 & W-106 & $<0.5$ & 22.5 & $<1.0$ & $<1.0$ & 11.5 & 26.2 \\
\hline 08 & W-108 & $<0.5$ & 1.7 & $<1.0$ & $<1.0$ & $<3.0$ & 36.9 \\
\hline 09 & W-109 & $<0.5$ & $<1.0$ & $<1.0$ & $<1.0$ & $<3.0$ & 36.7 \\
\hline 10 & W-110 & $<0.5$ & 21.59 & $<1.0$ & $<1.0$ & 11.65 & 25.6 \\
\hline 11 & W-111 & $<0.5$ & $<1.0$ & $<1.0$ & $<1.0$ & $<3.0$ & 35.8 \\
\hline BSTI [9] & & 1.0 & 250 & -- & -- & 4.5 & -- \\
\hline ECR-1997 [10] & & 1.0 & $150-600$ & $<1.0$ & -- & 10 & 400 \\
\hline
\end{tabular}

It was observed that Fluoride and Bromide value were less than less than $0.5 \mathrm{mg} / \mathrm{L}$ in all sampling area. Acceptable limit of Fluoride is $1.0 \mathrm{mg} / \mathrm{L}$ (BSTI and ECR-1997). Nitrite value of all samples showed less than $1.0 \mathrm{mg} / \mathrm{L}$ which compiles to ECR-1997. In case of Nitrate most of samples showed less than $3.0 \mathrm{mg} / \mathrm{L}$. The Nitrate value of $\mathrm{W}-103(14.2 \mathrm{mg} / \mathrm{L}), \mathrm{W}-$ $104(14.3 \mathrm{mg} / \mathrm{L}), \mathrm{W}-106(11.5 \mathrm{mg} / \mathrm{L})$ and $\mathrm{W}-110(11.65$ $\mathrm{mg} / \mathrm{L})$ ) were slightly higher than $4.5 \mathrm{mg} / \mathrm{L}$ (BSTI) and 10.0 $\mathrm{mg} / \mathrm{L}$ (ECR-1997). During water treatment the pumped water is conveyed to the biological pre-treatment units. Meteor hybrid growth system was installed to pre-treat the ammonia. The main purpose of the biological pretreatment is to reduce the ammonia concentration to prohibit the reaction of excessive ammonia in the raw water. Chloride value of all sampling areas are below to acceptable limit $250 \mathrm{mg} / \mathrm{L}$ (BSTI) and $150-600 \mathrm{mg} / \mathrm{L}$ (ECR-1997). W-103 showed the value of Chloride $59.2 \mathrm{mg} / \mathrm{L}$. Sulphate value were also below to recommended value of $400 \mathrm{mg} / \mathrm{L}$ (ECR-1997). Aluminum sulfate, lime, and chlorine are mainly used during water treatment. Aluminum Sulphate is used as a coagulant and is added in the mixing chamber before the clarifier. Chlorine is injected in the raw water or pre-treated water for prechlorination and after the filtration for post-chlorination (as disinfectant) [21-23] while the lime is used during the flocculation or in the clear water tank for $\mathrm{pH}$ adjustment [2426].

Table 5. Microbiological properties of drinking water.

\begin{tabular}{lllll}
\hline Serial no. & Sample No. & Total Viable Count (TVC), cfu/mL & Total Coliforms, MPN/mL & Fecal Coliforms, MPN/mL \\
\hline 01 & W-101 & 45 & $<0.2^{*}$ & $<0.2^{*}$ \\
02 & W-102 & 90 & $<0.2^{*}$ & $<0.2^{*}$ \\
03 & W-103 & 70 & $<0.2^{*}$ & $<0.2^{*}$ \\
04 & W-104 & 40 & $<0.2^{*}$ & $<0.2^{*}$ \\
05 & W-105 & 30 & $<0.2^{*}$ & $<0.2^{*}$ \\
06 & W-106 & 60 & $<0.2^{*}$ & $<0.2^{*}$ \\
07 & W-107 & 42 & $<0.2^{*}$ & $<0.2^{*}$ \\
08 & W-108 & 100 & $<0.2^{*}$ & $<0.2^{*}$ \\
09 & W-109 & 80 & $<0.2^{*}$ & $<0.2^{*}$ \\
10 & W-110 & 100 & $<0.2^{*}$ & $<0.2^{*}$ \\
11 & W-111 & 80 & $<0.2^{*}$ & $<0.2^{*}$ \\
Acceptable limit for drinking water & 1000 & Absent & Absent \\
according to BDS 1240:2001 & &
\end{tabular}

Total Coliforms and Fecal Coliforms of all collected samples showed less than $0.2 \mathrm{MPN} / \mathrm{mL}$ (most probable number $<0.2$ indicates absence of test organism in $1 \mathrm{~mL}$ ).
Total Viable Count (TVC) of all samples were less than 100 $\mathrm{cfu} / \mathrm{mL}$. Chlorination and post chlorination are appropriate tool to limit coliform [27]. 


\section{Conclusion}

From the analysis of drinking water at different areas around Dhaka city supplied by Dhaka DWASA, it can be inferred that water quality is well. Almost all observed parameters value of sampling areas complies the drinking water standard BDS 1240:2001 and ECR-1997. Some techniques improve the drinking water quality. Aerator increases the Dissolved oxygen level during row water treatment. Meteor hybrid growth system reduces the ammonia concentration in biological pre-treatment unit. Lime is used during the flocculation or in the clear water tank for $\mathrm{pH}$ adjustment. Post-chlorination is used as disinfectant of water. That's why supplied water is not micro-organism contaminated. Pollution control and better management River water quality are vital for the sustainability of the treatment plant to get healthy and safe drinking water.

\section{Acknowledgements}

The authors extend their gratitude to the authority of Institute of National Analytical Research and Service (INARS), Bangladesh Council of Scientific and Industrial Research (BCSIR), Dhanmondi, Dhaka, Bangladesh. This study was conducted with the financial support of ISO 17025:2017 Accredited laboratory of INARS.

\section{References}

[1] N. J. Zinia, P. McShane, "Ecosystem services management: An evaluation of green adaptations for urban development in Dhaka, Bangladesh," Landscape and urban planning, vol. 173, pp. 23-32, May 1, 2018.

[2] Available from https://dDWASA.org.bd/[last accessed on 2019 November 11].

[3] S. Xiao, X. Lv, Y. Zeng, T. Jin, L. Luo, B. Zhang, G. Zhang, Y. Wang, L. Feng, Y. Zhu, T Tang, "Mutagenicity and estrogenicity of raw water and drinking water in an industrialized city in the Yangtze River Delta," Chemosphere, Vol. 185, pp. 647-55, Oct 1, 2017.

[4] M. Eda, S. Okino, R. Yoshiyama, H. Sakurai, N. Ukai, H. Suzuki, H. Nakashoji, S. Yoshioka, inventors; "Mitsubishi Heavy Industries Engineering Ltd, assignee. Water treatment process and water treatment system, "United States patent US 10,160,671. Dec 25, 2018.

[5] J. N. Hakizimana, B. Gourich, M. Chafi, Y. Stiriba, C. Vial, P. Drogui, J. Naja, "Electrocoagulation process in water treatment: A review of electrocoagulation modeling approaches, " Desalination, vol. 404, pp. 1-21, February 17, 2017.

[6] S. Zhang, S. W. Gitungo, L. Axe, R. F. Raczko, J. E. Dyksen, "Biologically active filters-an advanced water treatment process for contaminants of emerging concern," Water research, Vol. 114, pp. 31-41, May 1, 2017.

[7] Available from http://www.jwrcnet.or.jp/aswin/en/newtap/report/NewTap_037.pdf [last accessed on 2019 November 11].
[8] S. Ledakowicz, R. Żyłła, K. Paździor, J. Wrębiak, J. SójkaLedakowicz, "Integration of ozonation and biological treatment of industrial wastewater from dye house," Ozone: Science \& Engineering, vol. 39, no. 5, pp. 357-65, September $3,2017$.

[9] R. Fares, A. Aissa, A. Bouadi, M. Lounis. "Biological Treatment of Wastewater by Addition of Activated Carbon Powder (CAP)," J Waste Recycle, vol. 3, no. 1 (2), 2018.

[10] M. B. Ahmed, J. L. Zhou, H. H. Ngo, W. Guo, N. S. Thomaidis, J. Xu. "Progress in the biological and chemical treatment technologies for emerging contaminant removal from wastewater: a critical review," Journal of hazardous materials vol. 323, part-A pp. 274-98, February 5, 2017.

[11] M. A. Mahmud, K. A. Hussain, M. Hassan, A. R. Jewel, S. Z. Shamsad, "Water quality assessment using physiochemical parameters and heavy metal concentrations of circular rivers in and around Dhaka city," Bangladesh. International Journal of Water Research, vol. 7, no. 1, pp. 23-9, June 7, 2017.

[12] M. Islam, M. Uddin, S. Tareq, M. Shammi, A. Kamal, T. Sugano, M. Kurasaki, T. Saito, S. Tanaka, H. Kuramitz,"Alteration of water pollution level with the seasonal changes in mean daily discharge in three main Rivers around Dhaka City, Bangladesh," Environments, vol. 2, no. 3, pp-280-94, 2015.

[13] C. P. Rampley, P. G. Whitehead, L. Softley, M. A. Hossain, L. Jin, J. David, S. Shawal, P. Das, I. P. Thompson, W. E. Huang, R. Peters, "River toxicity assessment using molecular biosensors: Heavy metal contamination in the Turag-BaluBuriganga river systems, Dhaka, Bangladesh," Science of the Total Environment, vol. 703 ( 134760), October 31, 2019.

[14] S. M. Didar-Ul Islam, G. Azam, "Seasonal variation of physicochemical and toxic properties in three major Rivers; Shitalakhya, Buriganga and Turag around Dhaka city, Bangladesh," Journal of Biodiversity and Environmental Sciences (JBES), vol. 7, no. 3, pp. 120-131, 2015.

[15] L. S. Clesceri, A. E. Greenberg, A. D. Eaton, editors. "Standard methods for examination of water and wastewater," 20th ed. Washington, DC: American Public Health Association, 1998.

[16] M. A. Ahsan, F. Satter, M. A. Siddique, M. A. Akbor, S. Ahmed, M. Shajahan, MA. R. Khan, "Chemical and physicochemical characterization of effluents from the tanning and textile industries in Bangladesh with multivariate statistical approach," Environmental monitoring and assessment. vol. 191, no. 9 (575) September 1, 2019.

[17] M. A. Ahsan, M. A. Siddique, M. A. Munni, M. A. Akbor, U. H. Bithi, M. Y. Mia. "Analysis of major heavy metals in the available fish species of the Dhaleshwari River, Tangail, Bangladesh,” Int J Fish Aquat Stud, vol. 6, no. 4, pp. 349-54, 2018.

[18] Available from https://en.wikipedia.org/wiki/Bangladesh_Standards_and_Test ing_Institution [Last accessed on 2019 November 11].

[19] DoE "The Environment conservation Rules: Schedule 3, Government of the People's Republic of Bangladesh" Ministry of Environment \& Forest, 1997.

[20] F. Kožíšek, "Health significance of drinking water calcium and magnesium," Environmental Research Section, vol. 1, no. 84, pp. 219-27, February, 2003. 
[21] H. M. Kalibbala, R. Kaggwa, O. Wahlberg, E. Plaza, "Characteristics of natural organic matter and formation of chlorination by-products at Masaka waterworks," Journal of Water Supply: Research and Technology-Aqua, vol. 60, no. 8, pp. 511-519, 2011.

[22] A. A. Cuthbertson, S. Y. Kimura, H. K. Liberatore, R. S. Summers, D. R. Knappe, B. D. Stanford, J. C. Maness, R. E. Mulhern, M. Selbes, S. D. Richardson. "Does granular activated carbon with chlorination produce safer drinking water? From disinfection byproducts and total organic halogen to calculated toxicity," Environ. Sci. Technol, vol. 53, no. 10, pp. 5978-99, May 21, 2019.

[23] J. Hu, W. Chu, M. Sui, B. Xu, N. Gao, S. Ding S, "Comparison of drinking water treatment processes combinations for the minimization of subsequent disinfection by-products formation during chlorination and chloramination," Chemical Engineering Journal, vol. 335, pp. 352-61, March 1, 2018.
[24] R. Jiao, R. Fabris, C. W. Chow, M. Drikas, J. van Leeuwen, D. Wang, Z. Xu. "Influence of coagulation mechanisms and floc formation on filterability," Journal of Environmental Sciences, vol. 57, pp. 338-45, July 1, 2017.

[25] E. Balladares, O. Jerez, F. Parada, L. Baltierra, C. Hernández, E. Araneda, V. Parra, "Neutralization and co-precipitation of heavy metals by lime addition to effluent from acid plant in a copper smelter," Minerals Engineering, vol. 122, pp. 122-29, June, 2018.

[26] E. S. Agudosi, E. C. Abdullah, N. M. Mubarak, M. Khalid, M. Y. Pudza, N. P. Agudosi, E. D. Abutu, "Pilot study of in-line continuous flocculation water treatment plant," Journal of environmental chemical engineering, vol. 6, no. 6, pp. 718591, December 1, 2018.

[27] C. Bertelli, S. Courtois, M. Rosikiewicz, P. Piriou, S. Aeby, S. Robert, J. F. Loret, G. Greub, "Reduced chlorine in drinking water distribution systems impacts bacterial biodiversity in biofilms," Frontiers in microbiology, vol. 9, Article. 2520, 2018. 